
$\$$ Research Square
Preprints are preliminary reports that have not undergone peer review.
They should not be considered conclusive, used to inform clinical practice, or referenced by the media as validated information

\title{
The Clinical and Genetic Characteristics of Chinese Male Pediatric Patients with Congenital Hypogonadotropic Hypogonadism
}

\author{
Yi Wang \\ Miao Qin \\ Beijing Children's Hospital, Capital Medical University \\ Lijun Fan \\ Beijing Children's Hospital, Capital Medical University \\ Beibei Zhang \\ Beijing Children's Hospital, Capital Medical University \\ Chunxiu Gong ( $\nabla$ chunxiugong@sina.com ) \\ Beijing Children's Hospital, Capital Medical University
}

Beijing Children's Hospital, Capital Medical University https://orcid.org/0000-0002-8378-6613

\section{Research Article}

Keywords: congenital hypogonadotropic hypogonadism, clinical and genetic characteristics, oligogenicity, dual $\mathrm{CHH}$, family history

Posted Date: September 21st, 2021

DOI: https://doi.org/10.21203/rs.3.rs-660182/v2

License: @) (7) This work is licensed under a Creative Commons Attribution 4.0 International License. Read Full License 


\section{Abstract}

Purpose冈Congenital hypogonadotropic hypogonadism $(\mathrm{CHH})$ are invided into Kallmann Syndrome (KS) and normosmic $\mathrm{HH}(\mathrm{nHH})$. The clinical and genetic characteristics of $\mathrm{CHH}$ are more studied in adults, but less in pre-adults.

Methods: Medical records of 126 patients with $\mathrm{CHH}$ at our hospital during 2008-2020 were evaluated.

Results: Totally, seven patients (5.6\%) had hypospadias. Among 49 patients with positive family history, delayed puberty, $\mathrm{KS} / \mathrm{nHH}$ and olfactory abnormalities accounted for $44.9 \%, 16.3 \%$, and $12.2 \%$, respectively. Sixty-five patients completed the hCG prolongation test, and T levels of 24 patients were lower than 100 $\mathrm{ng} / \mathrm{dl}$. $25 \mathrm{CHH}$-related genes were found in 78 patients, digenic mutations in 23 patients, and trigenic mutations in 3 patients. The most common pathogenic genes were FGFR1 (21.1\%), PROKR2 (17.9\%), ANOS1 (12.6\%) and CHD7 (12.6\%). The oligogenicity rate of common autosomal dominant heredity genes accounted for $50.0 \%$ (FGFR1, 10/20) and 33.3\% (CHD7, 4/12), of autosomal recessive heredity gene PROKR2 accounted for 47.1\% (8/17). And W178S accounted for $58.8 \%$ of all mutations in PROKRR2.

Conclusion: Micropenis and cryptorchidism are important cues for $\mathrm{CHH}$ in pre-adulthood; hypospadias is a rare phenotype of $\mathrm{CHH}$. At least $22.9 \%$ of patients tested had testicular Leydig cell dysfunction (dual $\mathrm{CHH}$ ). Oligogenic mutations were found in $27.4 \%$ of all patients with $\mathrm{CHH}$. W178S in PROKRR2 maybe a founder mutation in Chinese $\mathrm{CHH}$ crowds.

\section{Introduction}

Congenital hypogonadotropic hypogonadism ( $\mathrm{CHH}, \mathrm{MIM} 615267)$ is a common cause of puberty absent, and adult infertility, with an incidence rate of 1 per 4000 new births [1]. When associated with anosmia or hyposmia, it is also known as Kallmann syndrome (KS, MIM 147950), and when associated with a normal sense of smell, it is termed normosmic $\mathrm{CHH}(\mathrm{nHH})$, with $\mathrm{KS}$ accounting for $50 \%$ of cases [2]. There are approximately $1200-1500$ gonadotropinreleasing hormone $(\mathrm{GnRH})$ neurons in the vertebrate hypothalamus, which can synthesize and release $\mathrm{GnRH}$. $\mathrm{CHH}$ is caused by a deficiency in the synthesis, release, or action of $\mathrm{GnRH}$, resulting in insufficient secretion of gonadotropins, followed by gonadal dysfunction. According to our previous research, a considerable number of patients may also have primary testicular Leydig cell dysplasia, namely dual $\mathrm{CHH}[3,4]$.

According to its pathophysiology, $\mathrm{CHH}$ is mainly divided into two types: during the fetal period, neurodevelopmental gene mutations cause disorders in the development, differentiation, or migration of GnRH neurons, usually causing KS. Defects in GnRH synthesis, release, or action on pituitary gonadotropin cells caused by neuroendocrine gene mutations usually lead to $\mathrm{nHH}$ [1]. An increasing number of studies have found that $\mathrm{CHH}$ could be caused by gene defects that affect both neuronal development and the GnRH signaling pathway. Mutations in the same CHH-related pathogenic gene often cause phenotypic differences among patients or individuals in the same family, that is, the low penetrance of most genes suggests that $\mathrm{CHH}$ is not a strict monogenic disease $[5,6]$. Studies including large $\mathrm{CHH}$ cohorts suggest that at least $20 \%$ of cases are oligogenic [6, 7]. However, our previous study of 64 patients indicated that oligogenic mutations accounted for only $9.8 \%$ [8].

Since the first KS-related pathogenic gene ANOS1 was cloned in 1991, an increasing number of CHH-related pathogenic genes have been identified. In 2015, the European $\mathrm{CHH}$ consensus summarized 31 pathogenic genes, including X-chromosome-linked recessive, autosomal recessive, and dominant genes [1]. At present, more than 90 candidate genes may be involved in the pathogenesis of $\mathrm{CHH}$, and some newly reported genes have been confirmed in $\mathrm{CHH}$ patients; some genes involved in $\mathrm{GnRH}$ neuronal migration and axon formation in animal models have not been confirmed in $\mathrm{CHH}$ patients [7, 9-15]. In our previous study, only 10 pathogenic genes were confirmed in $\mathrm{CHH}$ patients [8].

Therefore, this study evaluated 126 male patients with $\mathrm{CHH}$ and aimed to further study and deepen the understanding of the relationship between genotype and phenotype, so as to provide a reference for early diagnosis and intervention of pediatric $\mathrm{CHH}$.

\section{Materials And Methods}

\section{Editorial policies and ethical considerations}

The study was approved by the Ethics Committee of Beijing Children's Hospital, Capital Medical University, and written informed consent was obtained from the patients' parents or legal guardians. All data involved in the study could be available if necessary.

\section{Subjects}

A total of 126 male patients of Chinese Han nationality aged 0-18 years who were treated at the endocrine clinic of our hospital between 2008 and 2020 were enrolled. Except for one pair of siblings, none of the other patients were related to each other.

The diagnosis was made based on the phenotype, physical signs, chromosome karyotype, sex hormone levels including AMH and INHB, olfactory bulb MRI, hCG test, genetic test and etc.

\section{Inclusion and exclusion criteria}

Refer to previous literature reports [8].

\section{The diagnostic criteria of micropenis}

Refer to the literature of the Chinese Journal of Pediatric Surgery from 2010. 
After the hCG prolongation test, the level of T still less than $100 \mathrm{ng} / \mathrm{dl}$ was diagnosed as dual $\mathrm{CHH}$. If the hCG prolongation test was not performed, the level of T less than $100 \mathrm{ng} / \mathrm{dl}$ after treatment with $\mathrm{GnRH}$ (5-10 ug/90 min, 16 pulses/d) for half a year, was diagnosed as dual $\mathrm{CHH}$. If the hCG prolongation test was not performed and the GnRH treatment was provided for less than half a year and the level of T was still greater than $100 \mathrm{ng} / \mathrm{dl}$, it was considered that the testicular Leydig cells had a good response.

\section{HCG standard test, hCG prolonged test}

Please refer to a previously published article [8].

\section{Hormone detection}

LH, FSH, and T levels were detected using an enzyme-enhanced chemiluminescence immunoassay (Immulite 2000, Siemens Corporation, Munich, Germany).

\section{DNA sequence analysis}

A total of 51 patients underwent a gonadal panel, which included 164 genes, and 44 patients underwent whole exosome sequencing. DNA was extracted from peripheral blood leukocytes of patients and their parents and/or siblings, and the NEXTSEQ 500 sequencer (Illumina Corporation, San Diego, CA, USA) was used to filter out all possible pathogenic missense, frameshift, and splice site mutations. Design primers and Sanger sequencing were used to verify the mutations in the samples, and pathogenicity was judged according to ACMG rules; pathogenic, likely pathogenic, or uncertain mutations were considered to be possibly related to the disease.

\section{Statistical analysis}

Data analysis was performed using statistical product and service solutions 26.0 software (SPSS, International Business Machines Corporation, Armonk, NY, USA).

\section{Results}

\section{Clinical characteristics}

The chromosomes of all patients were $46 \mathrm{XY}$ and SRY (+). Combined with the phenotypes, physical signs, hormone levels, presence of puberty, olfactory bulb imaging, and genetic test results, a total of 126 cases of $\mathrm{CHH}$ were diagnosed, including 88 cases of $\mathrm{KS}(69.8 \%), 37 \mathrm{cases}$ of $\mathrm{nHH}(29.4 \%)$, and $1 \mathrm{case}$ of CHARGE syndrome (Fig. 1A, supplemantary table).

In total, $78.9 \%$ of the patients $(101 / 126)$ had micropenis, including cases of micropenis $(38.1 \%, 48 / 126)$, micropenis with cryptorchidism (35.2\%, $45 / 126)$, micropenis with cryptorchidism and hypospadias $(2.4 \%, 3 / 126)$, micropenis with hypospadias $(3.2 \%, 4 / 126)$, cryptorchidism $(8.7 \%, 11 / 126)$, and only absent puberty $(11.9 \%, 15 / 126)$ (Fig. 1B and Table 1).

Two patients with KS had left renal agenesis (one with ANOS1 mutation and the other without gene detection). One patient with FGFR1 mutation showed a positive joint movement of the limbs. A total of $65 \mathrm{KS}$ patients completed MRI examination of the olfactory bulb, and $7.7 \%(5 / 65)$ reported hyposmia, but no abnormal olfactory bulb, olfactory tract, or olfactory sulcus was found on MRI. A normal olfactory was reported in $30.8 \%$ of the cases (20/65), but structural abnormalities of the olfactory bulb, olfactory bundle, and/or olfactory sulcus could be seen on MRI, which was consistent with the results found in the literature and our previous reports.

\section{Genetic characteristics}

A total of 95 patients underwent genetic testing: $25 \mathrm{CHH}$-related pathogenic genes were found in $82.1 \%$ of cases (78/95) (Fig. 2A), digenic mutations in $24.2 \%$ of cases (23/95), and trigenic mutations in $3.2 \%$ of cases (3/95) (Table 2, Fig. 2B and $2 \mathrm{C})$.

The most common gene mutations were FGFR1 (20/95, 21.1\%), PROKR2 (17/95, 17.9\%), ANOS1 (12/95, 12.6\%), and CHD7 (12/95, 12.6\%) mutations. Among the most common gene mutations, there was no significant difference in the proportion of $F G F R 1, P R O K R 2$, and $C H D 7$ mutations in $\mathrm{KS}$ or $\mathrm{nHH}$ (all $\mathrm{p}>0.05$ ).

The majority of mutations in $\mathrm{CHH}$ probands were private, except for PROKR2 (p. W178S, $\mathrm{n}=5$ in KS and nHH, respectively), ANOS1 (p. V560I, $\mathrm{n}=2$ in KS), HS6ST1 (p. H63D, n=3 in KS), and IL 17RD mutations (p. P191L and p. S671L, n=2 in KS, respectively) (Fig. 2A).

The oligogenicity of common autosomal dominant inherited pathogenic genes accounted for $50 \%(F G F R 1,10 / 20)$ and $33.3 \%(C H D 7,4 / 12)$, the oligogenicity of autosomal recessive inherited pathogenic genes accounted for $47.1 \%$ (PROKR2, 8/17, Fig. 2D), and the oligogenicity of X-linked genes accounted for 8.3\% (ANOS1, 1/12). Among the 12 patients with CHD7 mutations, only one patient (8.3\%) was diagnosed with CHARGE syndrome. Among the 12 patients with KS caused by ANOS1 mutation, two patients were brothers with deletion of exons 1 and 2, and all exon deletion was noted in one patient.

We further analyzed the common pathogenic gene mutation sites according to ACMG and found that $45.5 \%-75.0 \%$ of the mutation sites were pathogenic or likely pathogenic, except for one case of $\mathrm{CHD7}$ mutation being likely benign, and the rest of these patients had either single-gene or oligogenic mutations (Fig. 2E).

\section{Dual $\mathrm{CHH}$ and genes}


In total, 105 patients completed the hCG standard test conducted to evaluate testicular Leydig cell function among 126 patients. Of these 105 patients, $68.6 \%$ (72/105) of patients had T< $100 \mathrm{ng} / \mathrm{dl}$, of which 65 patients completed the HCG prolongation test, and 22.9\% (24/105) of patients had T< $100 \mathrm{ng} / \mathrm{dl}$, suggesting testicular Leydig cell dysfunction; therefore, at least $22.9 \%$ of cases could be diagnosed as dual $\mathrm{CHH}$ (Fig. 3 ).

\section{Family history and genes}

Among 49 patients with positive family histories, $44.9 \%$ (22/49) had a family history of delayed puberty (DP). In addition to the CHH-related genes (FGFR1, HS6ST1, IL 17RD, and SEMA3A) reported in the literature in patients with DP [16, 17], two patients carried PROKR2 mutations from late-developing mothers (menarche at 16 years), and one patient carried KISS1R mutations from a late-developing father (first spermatorrhea at the age of 18-19 years). It is suggested that PROKR2 and KISS1R may also be shared genes of DP and $\mathrm{CHH}$.

Six patients had a family history of hyposmia or anosmia (three cases were also associated with family history of DP). In this study, two patients with KS were siblings with deletion of exons 1 and 2 of $A N O S 1$, and their elder brother who was diagnosed with KS carried the same mutation and received treatment with a GnRH pump in another hospital; the other two patients with KS both had an elder brother who were diagnosed with KS, and carried an ANOS1 missense mutation; and one patient with $\mathrm{nHH}$ had K1SS1R compound heterozygous mutations and his elder sister carried the same mutation and had no breast development and menarche at the age of 17 years. Four patients had a family history of disorders of sex development (DSD), and three mothers were probands (Fig. 4). The three mothers were all treated with estrogen and progesterone to regulate their menstrual cycles. When they had fertility needs, they were administered $\mathrm{GnRH}$ pump therapy combined with assisted reproductive technology, and they carried three gene mutations (IL17RD mutation p. N503S; FGFR1 mutation p. P176S; PROKR2 mutation p. W178S).

\section{Discussion}

This study summarized the clinical and genetic characteristics of 126 patients, using $\mathrm{CHH}$ and DSD phenotypes (micropenis and cryptorchidism) and genetic testing as important cues for pediatric diagnosis of $\mathrm{CHH}$. With an increase in the number of cases, more $\mathrm{CHH}$ candidate genes were confirmed in patients. We found that digenic and trigenic variants accounted for $24.2 \%(23 / 95)$ and $3.2 \%(3 / 95)$ of patients, respectively, who underwent genetic testing.

The proportion of gene mutations found in patients in this study was significantly higher than that in patients with $\mathrm{CHH}$ reported in the literature. The most common mutant genes were FGFR1 (21.1\%), PROKR2 (17.9\%), ANOS1 (12.6\%), and CHD7 (12.6\%) [6, 7, 18-20]. Among them, 10 cases (50.0\%) of FGFR1 and 7 cases $(41.2 \%)$ of $P R O K R 2$ mutations were oligogenic mutations. Previous studies reported that FGFR1 mutation may be related to hand and foot malformation in patients with $\mathrm{CHH}$ [19]; however, in this study, only one patient with hand and foot malformation had FGFR1 mutation, and there was no obvious phenotypic-genotypic correlation, which may be because more than half of the patients were oligogenic.

Previous literature on $\mathrm{HH}$ in adults reported that patients with FGFR1 mutations had a high incidence of cryptorchidism, small testicular size, long treatment time for spermatogenesis, and low sperm concentration [21]. However, in this study, compared with patients with non- FGFR1 mutations, the incidence of cryptorchidism in patients with FGFR1 mutation was not significantly higher, the testicular volume was not small, and the patients with FGFR1 mutations had mainly pure $\mathrm{CHH}$. However, because the diagnosis of pure $\mathrm{CHH}$ in this study was based on the $\mathrm{T}$ level after the hCG prolongation test, which may be the cause of the difference, further follow-up studies will be conducted.

INHB is a marker of the number of Sertoli cells, and is usually lower than $30 \mathrm{pg} / \mathrm{ml}$ in male patients with complete $\mathrm{CHH}[1,22]$. In some patients with partial $\mathrm{CHH}$, the level of INHB may overlap with that of DP and healthy controls [23,24]. In this study, the INHB test was performed in 65 patients, including all age groups, of which 45 (69.2\%) had an INHB level of $>30 \mathrm{pg} / \mathrm{ml}$, suggesting that the function of testicular Sertoli cells in these patients was still good. After subsequent therapy with $\mathrm{GnRH}$ pump or HCG/HMG, it was more likely to promote spermatogenesis, which was consistent with the current spermatogenesis rate of $64-80.3 \%$ in $\mathrm{CHH}$ patients after treatment $[25,26]$. Among the 39 patients with $\mathrm{T}>100 \mathrm{ng} / \mathrm{dl}$ after the hCG prolongation test, there were still 10 patients whose INHB level was less than $30 \mathrm{pg} / \mathrm{ml}$, suggesting that some of the patients with good response to Leydig cells may still have had poor function of Sertoli cells. Therefore, the evaluation of testicular cell function in patients with $\mathrm{HH}$ requires a multi-faceted and multi-index comprehensive evaluation.

However, in this study, one patient with three gene mutations (SEMA3E/CHD7/NSMF) was also diagnosed with dual CHH. The patient was treated with a standard GnRH pump for 6 months, the level of T was $112 \mathrm{ng} / \mathrm{dl}$, and 12 months later, it was observed that the patient had spermatorrhea and good sperm motility and concentration. Therefore, the percentage of patients diagnosed with dual $\mathrm{CHH}$ in this study with restored fertility after treatment needs to be further studied. This phenomenon also suggests that there was a false negative response to short-term stimulation in the experiment.

In previous studies of adult cases, patients whose puberty was not induced by hormone therapy at the age of puberty usually showed infertility when GnRH pump therapy was used to stimulate spermatogenic potential in adults. Therefore, for $\mathrm{CHH}$ patients and their families, every gene mutation that causes $\mathrm{GnRH}$ deficiency should theoretically not be transmitted within the family. Recent studies have shown that a small number of gene mutation sites have strikingly high percentage, such as GNRHR Q106R (44\%), GNRHR R262Q (29\%) [6, 27-29] and TACR3 W275X (36\%) [30-32]. The L173R of PROKR2 accounts for 40\% of the $\mathrm{CHH}$ population in Europe and the United States, but it is rare in the Asian population [6, 33-36]. The recurrent mutation sites of several genes in this study were PROKR2 (p. W178S, $\mathrm{n}=5$ in KS and $\mathrm{nHH}$, respectively), ANOS1 (p. V560I, $\mathrm{n}=2$ in KS), HS6ST1 (p. H63D, $\mathrm{n}=3$ in KS), and IL 17RD (p. P191L and p. $\mathrm{S} 671 \mathrm{~L}, \mathrm{n}=2$ in $\mathrm{KS}$, respectively). It was proven that $P R O K R 2$ was one of the most common pathogenic genes in $\mathrm{CHH}$, accounting for $17.9 \%$ (17/95) in this study, of which W178S accounted for 58.8\% (10/17). In another study of Chinese adult CHH patients, PROKR2 mutations accounted for $13.3 \%$ (18/135) and W178S accounted for $55.6 \%$ (10/18) [37]. Combined with two studies, W178S accounted for $57.1 \%$ of PROKR2 mutations in the Chinese CHH population (20/35). Functional analysis showed that the mutant impeded receptor was expressed on the cell surface. The W178S of $P R O K R 2$ may be an ancient founder mutation, and it was not eliminated in the Chinese $\mathrm{CHH}$ population during evolution. The silencing of its effect on reproduction may be related to oligogenicity, or the mutant may revert during adulthood. However, in this study, the mother of one patient harboring W178S in PROKR2 was a proband, suggesting that the

Page $4 / 14$ 
mutation had a wide spectrum and that the patient could undergo germ cell maturation after treatment. Therefore, the complex mechanism of its effect on reproduction needs to be further studied.

Of the five patients with single-gene mutations in PROKR2 (W178S), four were diagnosed with dual CHH. Some patients carried additional gene mutations. One patient with a repetitive mutation site HS6ST1 (H63D) and another with IL 17RD (N503S) were also diagnosed with dual CHH, and PROKR2 (W178S) and IL17RD (N503S) were carried by the proband mother simultaneously; however, the results of the HCG test showed that the Leydig cells were dysfunctional. It has been suggested that some patients with dual $\mathrm{CHH}$ diagnosed by the hCG test in this study may still recover their reproductive function after standard treatment, and it is possible that Leydig cells had not been stimulated by GnRH for a long time, which may have led to the slow response of the receptor. The curative effects in the patients with the above mutations and the relationship between the curative effect and gene mutations will be further investigated. However, the FGFR1 mutation with the highest proportion of mutations was not found to be recurrent in patients with $\mathrm{CHH}$, suggesting that the mutations of the gene had a greater impact on reproduction. Among the 126 patients in this study, three probands were mothers, and no probands were fathers. It has been reported that $64-80.3 \%$ of male $\mathrm{CHH}$ patients could produce sperms after GnRH pump or HCG/HMG therapy, but the specific situation may need further observation.

Hypospadias is caused by an abnormal urethral opening closure in the early stage of embryonic development, including the early hormone-independent stage (5-8 weeks) and hormone-dependent stage (8-12 weeks) [38]. There was no significant intersection with the functional time of the HPG axis. Therefore, hypospadias and $\mathrm{CHH}$ may be two unrelated diseases. The $2015 \mathrm{CHH}$ consensus also believes that the existence of the hypospadias phenotype can exclude the diagnosis of hypospadias [1].

In addition to our previous report, other $\mathrm{HH}$ patients with the hypospadias phenotype have also been reported; for example, Huseyin et al. reported that a 15year-old boy had no puberty initiation, micropenis, cryptorchidism, and perineal scrotal hypospadias, and his elder sister had no secondary sexual development. Sequencing showed that they carried KISS1R homozygous mutations (p. Y323X) [39]. In 2017, Ji et al. reported that a 28-year-old KS patient presented with no signs of puberty, bilateral cryptorchidism, olfactory loss, and right deafness. Genetic tests found that in addition to nonpathogenic variants (rs808119, rs6185) of ANOS1 and GNRH1, SRD5A2 gene heterozygous variation (c.680G > A) was also present, and T/DHT was 26.40, after the hCG test; thus, it was considered that the patient had KS and 5 a-RD [40]. In Indonesia, 11 patients with $46, \mathrm{XY}$ DSDs were reported to carry pathogenic mutations, including PROKR2, PROK2, WDR11, FGFR1, and CHD7 mutations, and these patients had different degrees of hypospadias [41]. Other studies have found that FGF8, $G L / 3, C H D 7$, and other $\mathrm{CHH}$-related genes could cause hypospadias ${ }^{38}$. These studies suggest that hypospadias and $\mathrm{CHH}$ are not completely separated, and the potential relationship between hypospadias and $\mathrm{CHH}$ needs to be further elucidated. There were seven patients with hypospadias in this study, but five carried no hypospadias related genes, one with KS had SALL1 gene mutation (p. M662V), and one with nHH had a SPECCIL mutation (p. M232V). SALL1 and SPECC1L gene mutations could cause hypospadias, suggesting that the combined gene mutation may be one of the causes of hypospadias in patients with $\mathrm{CHH}$, but the mechanism of hypospadias in other patients is still not clear.

\section{Conclusion}

Micropenis, cryptorchidism, and molecular genetics are important cues for diagnosing $\mathrm{CHH}$ in pediatric patients. Hypospadias is a rare $\mathrm{CHH}$ phenotype. Oligogenic mutations accounted for $27.4 \%$ of all $\mathrm{CHH}$ patients, which may have been a mechanism of autosomal recessive heredity genes or incomplete gene penetrance pathogenicity. KS due to ANOS1 mutations was mostly caused by single genes, and $\mathrm{CHD7}$ mutations led to isolated $\mathrm{CHH}$. Approximately $25.0-$ $54.5 \%$ of the common pathogenic gene mutations are uncertain, and their roles in the pathogenesis of $\mathrm{CHH}$ require further study. PROKR2 and KISS1R may also be shared genes involved in DP and $\mathrm{CHH}$. The FGF signaling pathway, represented by FGFR1, mainly causes pure $\mathrm{CHH}$. The mothers of multiple probands carried the same mutation and multiple gene mutation sites appeared repeatedly, suggesting that the effect of these mutation sites on reproduction was relatively slight. In this study, T after short-term hCG stimulation as an indicator of testicular function may be a false negative. We will further monitor the levels of $\mathrm{T}$ and INHB in patients with $\mathrm{CHH}$ after $\mathrm{GnRH}$ pump or $\mathrm{HCG} / \mathrm{HMG}$ treatment, and discuss dual $\mathrm{CHH}$.

\section{Abbreviations}

$\mathrm{CHH}$ : Congenital hypogonadotropic hypogonadism; KS: Kallmann Syndrome; nHH: normosmic HH; GnRH: Gonadotropin-releasing hormone; DP: Delayed puberty; DSD: Disorders of sex development.

\section{Declarations}

\section{Acknowledgements}

We thank all the patients and their parents for participating in the study.

\section{Authors' contributions}

MQ, LF and BZ collected the data. YW analyzed the data and wrote the manuscript. CG revised the manuscript. All authors approved the final version of the manuscript.

\section{Funding}

The Pediatric Medical Coordinated Development Center of Beijing Hospitals Authority (XTYB201808), the Public Health Project for Residents in Beijing (Z151100003915103), and the National Key Research and Development Program of China (2016YFC0901505). 


\section{Conflict of interests}

The authors declare that there is no conflict of interests.

\section{Availability of data and materials}

All relevant data are within the paper, any additional information about the cohorts may be made available upon request addressed to the corresponding author, pending the approval of the Institutional Review Board of the Beijing Children's Hospital, Capital Medical University.

\section{Consent for publication}

The authors have obtained the patient's written informed consent for print and electronic publication of the study.

\section{Ethics approval and consent to participate}

The study was approved by the Ethics Committee of Beijing Children's Hospital, Capital Medical University, and written informed consent was obtained from the patients' parents or legal guardians.

\section{References}

1. U. Boehm , P.M. Bouloux, M.T. Dattani, et al. Expert consensus document: European Consensus Statement on congenital hypogonadotropic hypogonadism-pathogenesis, diagnosis and treatment. Nat. Rev. Endocrinol. (2015)https://doi.org/10.1038/nrendo.2015.112

2. A.L. Mitchell, A. Dwyer, N. Pitteloud, R. Quinton, Genetic basis and variable phenotypic expression of Kallmann syndrome: towards a unifying theory. Trends Endocrinol. Metab. (2011) https://doi.org/10.1016/j.tem. 2011.03.002

3. R.P. Grinspon, N. Loreti, D. Braslavsky, et al. Spreading the clinical window for diagnosing fetal-onset hypogonadism in boys. Front. Endocrinol (Lausanne). (2014) https://doi.org/10.3389/fendo.2014.00051

4. G.P. Sykiotis, X.H. Hoang, M. Avbelj, et al. Congenital idiopathic hypogonadotropic hypogonadism: evidence of defects in the hypothalamus, pituitary, and testes. J. Clin. Endocrinol. Metab. (2010) https://doi.org/10.1210/jc.2009-2582

5. N. Pitteloud, R. Quinton, S. Pearce, et al. Digenic mutations account for variable phenotypes in idiopathic hypogonadotropic hypogonadism. J. Clin. Invest. (2007) https://doi.org/10.1172/JCl29884

6. G.P. Sykiotis, L. Plummer, V.A. Hughes, et al. Oligogenic basis of isolated gonadotropin-releasing hormone deficiency. Proc. Natl. Acad. Sci. USA. (2010); https://doi.org/10.1073/pnas.1009622107

7. H. Miraoui, A.A. Dwyer, G.P. Sykiotis, et al. Mutations in FGF17, IL17RD, DUSP6, SPRY4, and FLRT3 are identified in individuals with congenital hypogonadotropic hypogonadism. Am. J. Hum. Genet. (2013) https://doi.org/10.1016/j.ajhg.2013.04.008

8. Y. Wang, C. Gong, M. Qin, Y. Liu, Y. Tian, Clinical and genetic features of 64 young male paediatric patients with congenital hypogonadotropic hypogonadism. Clin. Endocrinol (Oxf). (2017) https://doi.org/10.1111/cen.13451

9. J.Bouilly, A. Messina, G. Papadakis, et al. DCC/NTN1 complex mutations in patients with congenital hypogonadotropic hypogonadism impair GnRH neuron development. Hum. Mol. Genet. (2018) https://doi.org/10.1093/hmg/ddx408

10. S.D. Quaynor, M.E. Bosley, C.G. Duckworth, et al. Targeted next generation sequencing approach identifies eighteen new candidate genes in normosmic hypogonadotropic hypogonadism and Kallmann syndrome. Mol. Cell Endocrinol. (2016) https://doi.org/10.1016/j.mce.2016.08.007

11. I. Turan, B.I. Hutchins, B. Hacihamdioglu, et al. CCDC141 Mutations in Idiopathic Hypogonadotropic Hypogonadism. J. Clin. Endocrinol. Metab. (2017) https://doi.org/10.1210/jc.2016-3391

12. T. Suter, A. Jaworski, Cell migration and axon guidance at the border between central and peripheral nervous system. Science. (2019) https://doi.org/10.1126/science.aaw8231

13. Z. Zhu, X. Han, Y. Li, et al. Identification of ROBO1/2 and SCEL as candidate genes in Kallmann syndrome with emerging bioinformatic analysis. Endocrine. (2020) https://doi.org/ 10.1007/s12020-019-02010-y

14. S. Barraud, B. Delemer, C. Poirsier-Violle, et al. Congenital Hypogonadotropic Hypogonadism with Anosmia and Gorlin Features Caused by a PTCH1 Mutation Reveals a New Candidate Gene for Kallmann Syndrome. Neuroendocrinology. (2021) https://doi.org/10.1159/000506640

15. R. Oleari, A. Caramello, S. Campinoti, et al. PLXNA1 and PLXNA3 cooperate to pattern the nasal axons that guide gonadotropin-releasing hormone neurons. Development. (2019) https://doi.org/10.1242/dev.176461

16. S.R. Howard, The Genetic Basis of Delayed Puberty. Front. Endocrinol (Lausanne). (2019) https://doi.org/10.3389/fendo.2019.00423

17. J. Zhu, R.E. Choa, M.H. Guo, et al. A shared genetic basis for self-limited delayed puberty and idiopathic hypogonadotropic hypogonadism. J. Clin. Endocrinol. Metab. (2015) https://doi.org/10.1210/jc.2015-1080

18. M.G. Au, W.F. Crowley, Jr., C.L. Buck, Genetic counseling for isolated GnRH deficiency. Mol. Cell. Endocrinol. (2011) https://doi.org/10.1016/j.mce.2011.05.041

19. C. Dode, J. Levilliers, F.M. Dupont, et al. Loss-of-function mutations in FGFR1 cause autosomal dominant Kallmann syndrome. Nat. Genet. (2003) https://doi.org/10.1038/ng1122

20. D. Wang, Y. Niu, J. Tan, et al. Combined in vitro and in silico analyses of FGFR1 variants: genotype-phenotype study in idiopathic hypogonadotropic hypogonadism. Clin. Genet. (2020) https://doi.org/10.1111/cge.13814

Page 6/14 
21. S. Li, Y. Zhao, M. Nie, et al. Clinical Characteristics and Spermatogenesis in Patients with Congenital Hypogonadotropic Hypogonadism Caused by FGFR1 Mutations. Int. J. Endocrinol. (2020) https://doi.org/10.1155/2020/8873532

22. N. Pitteloud, F.J. Hayes, P.A. BoeppleA, et al. The role of prior pubertal development, biochemical markers of testicular maturation, and genetics in elucidating the phenotypic heterogeneity of idiopathic hypogonadotropic hypogonadism. J. Clin. Endocrinol. Metab. (2002) https://doi.org/10.1210/jcem.87.1.8131

23. R. Coutant, E. Biette-Demeneix, C. Bouvattier, et al. Baseline inhibin B and anti-Mullerian hormone measurements for diagnosis of hypogonadotropic hypogonadism (HH) in boys with delayed puberty. J. Clin. Endocrinol. Metab. (2010) https://doi.org/10.1210/jc.2010-1535

24. L. Adan, P. Lechevalier, A.C. Couto-Silva, et al. Plasma inhibin B and antimullerian hormone concentrations in boys: discriminating between congenital hypogonadotropic hypogonadism and constitutional pubertal delay. Med. Sci. Monit. (2010)

25. G. Rastrelli, G. Corona, E. Mannucci, M. Maggi, Factors affecting spermatogenesis upon gonadotropin-replacement therapy: a meta-analytic study. Andrology. (2014) https://doi.org/10.1111/andr.262

26. M. Hao, M. Nie, B.Q. Yu, et al. Gonadotropin treatment for male partial congenital hypogonadotropic hypogonadism in Chinese patients. Asian. J. Androl. (2020) https://doi.org/10.4103/aja.aja_88_19

27. F. Cerrato, J. Shagoury, M. Kralickova, et al. Coding sequence analysis of GNRHR and GPR54 in patients with congenital and adult-onset forms of hypogonadotropic hypogonadism. Eur. J. Endocrinol. (2006) https://doi.org/10.1530/eje.1.02235

28. H.G. Kim, J. Pedersen-White, B. Bhagavath, L.C. Layman, Genotype and phenotype of patients with gonadotropin-releasing hormone receptor mutations. Front. Horm. Res. (2010) https://doi.org/10.1159/000312696

29. B. Bhagavath, M. Ozata, I.C. Ozdemir, et al. The prevalence of gonadotropin-releasing hormone receptor mutations in a large cohort of patients with hypogonadotropic hypogonadism. Fertil. Steril. (2005) https://doi.org/10.1016/j.fertnstert.2005.04.029

30. J. Young, J. Bouligand, B. Francou, et al. TAC3 and TACR3 defects cause hypothalamic congenital hypogonadotropic hypogonadism in humans. J. Clin. Endocrinol. Metab. (2010) https://doi.org/10.1210/jc.2009-2600

31. A.K. Topaloglu, F. Reimann F, M. Guclu, et al. TAC3 and TACR3 mutations in familial hypogonadotropic hypogonadism reveal a key role for Neurokinin B in the central control of reproduction. Nat. Genet. (2009) https://doi.org/10.1038/ng.306

32. E. Gianetti, C. Tusset, S.D. Noel, et al. TAC3/TACR3 mutations reveal preferential activation of gonadotropin-releasing hormone release by neurokinin B in neonatal life followed by reversal in adulthood. J. Clin. Endocrinol. Metab. (2010) https://doi.org/10.1210/jc.2009-2320

33. M. Avbelj Stefanija, M. Jeanpierre, G.P. Sykiotis, et al. An ancient founder mutation in PROKR2 impairs human reproduction. Hum. Mol. Genet. (2012) https://doi.org/10.1093/hmg/dds264

34. J. Sarfati, A. Guiochon-Mantel, P. Rondard, et al. A comparative phenotypic study of kallmann syndrome patients carrying monoallelic and biallelic mutations in the prokineticin 2 or prokineticin receptor 2 genes. J. Clin. Endocrinol. Metab. (2010) https://doi.org/10.1210/jc.2009-0843

35. C. Dode, L. Teixeira, J. Levilliers, et al. Kallmann syndrome: mutations in the genes encoding prokineticin-2 and prokineticin receptor-2. PLoS Genet. (2006) https://doi.org/10.1371/journal.pgen.0020175

36. L.W. Cole, Y. Sidis, C. Zhang, et al. Mutations in prokineticin 2 and prokineticin receptor 2 genes in human gonadotrophin-releasing hormone deficiency: molecular genetics and clinical spectrum. J. Clin. Endocrinol. Metab. (2008) https://doi.org/10.1210/jc.2007-2654

37. Y. Zhao, J. Wu, H. Jia, et al. PROKR2 mutations in idiopathic hypogonadotropic hypogonadism: selective disruption of the binding to a Galpha-protein leads to biased signaling. FASEB. J. (2019) https://doi.org/10.1096/fj.201801575R

38. A. Bouty, K.L. Ayers, A. Pask, Y. Heloury, A.H. Sinclair. The Genetic and Environmental Factors Underlying Hypospadias. Sex. Dev. (2015) https://doi.org/ $10.1159 / 000441988$

39. H. Demirbilek, M.N. Ozbek, K. Demir, et al. Normosmic idiopathic hypogonadotropic hypogonadism due to a novel homozygous nonsense c.C969A (p.Y323X) mutation in the KISS1R gene in three unrelated families. Clin. Endocrinol (Oxf). (2015) https://doi.org/10.1111/cen.12618

40. W. Ji, L.Y. Zhang, F.C. Li, et al. Genetic sequencing of a patient with Kallmann syndrome plus 5alpha-reductase type 2 deficiency. Asian J. Androl. (2017) https://doi.org/10.4103/1008-682X.170865

41. K.L. Ayers, A. Bouty, G. Robevska, et al. Variants in congenital hypogonadotrophic hypogonadism genes identified in an Indonesian cohort of 46,XY undervirilised boys. Hum. Genomics. (2017) https://doi.org/10.1186/s40246-017-0098-2

\section{Tables}

Table 1 Genetic results of 7 patients with hypospadias 


\begin{tabular}{|c|c|c|c|c|c|c|c|c|c|c|c|c|}
\hline No. & $\begin{array}{l}\text { Date of } \\
\text { birth }\end{array}$ & Diagnosis & $\begin{array}{l}\text { Age* } \\
\text { (yrs) }\end{array}$ & $\begin{array}{l}\text { First } \\
\text { gene }\end{array}$ & Nucleotide & $\begin{array}{l}\text { Amino } \\
\text { acid }\end{array}$ & $\begin{array}{l}\text { Second } \\
\text { gene }\end{array}$ & Nucleotide & $\begin{array}{l}\text { Amino } \\
\text { acid }\end{array}$ & $\begin{array}{l}\text { Third } \\
\text { gene }\end{array}$ & Nucleotide & $\begin{array}{l}\text { Aminc } \\
\text { acid }\end{array}$ \\
\hline 1 & $2012 / 3 / 15$ & $\mathrm{KS}$ & 0.42 & HS6ST1 & c. $187 \mathrm{C}>\mathrm{G}$ & p.H63D & SALL1 & c. $1984 A>G$ & p.M662V & & & \\
\hline 2 & $2003 / 7 / 3$ & $\mathrm{KS}$ & 3.42 & ANOS1 & c. $958 G>A$ & p.E320K & & & & & & \\
\hline 3 & $2000 / 9 / 11$ & $\mathrm{KS}$ & 9 & FGF17 & c. $359 \mathrm{C}>\mathrm{T}$ & p.P120L & & & & & & \\
\hline 4 & $2005 / 8 / 30$ & $\mathrm{KS}$ & 10.17 & CHD7 & c. $3247 A>G$ & p.T1083A & CHD7 & c. $6379 G>A$ & p.A2127T & HS6ST1 & c. $1177 \mathrm{G}>\mathrm{A}$ & p.D39: \\
\hline 5 & $2003 / 9 / 26$ & $\mathrm{KS}$ & 12 & ANOS1 & c. $1678 G>A$ & p.V560l & & & & & & \\
\hline 6 & $2017 / 5 / 6$ & $\mathrm{nHH}$ & 3.25 & PROKR2 & c. $472 \mathrm{G}>\mathrm{A}$ & p.V158I & SPECC1L & c. $694 A>G$ & p.M232V & & & \\
\hline 7 & $2009 / 6 / 4$ & $\mathrm{nHH}$ & 14 & Negative & & & & & & & & \\
\hline
\end{tabular}

*: Age at diagnosis.

Table 2 Oligogenic mutations of 26 patients 


\begin{tabular}{|c|c|c|c|c|c|c|c|}
\hline Case & Diagnosis & $\begin{array}{l}\text { Number of } \\
\text { gene }\end{array}$ & $\begin{array}{l}\text { Number of Mutant } \\
\text { Alleles }\end{array}$ & Gene & Nucleotide Change & $\begin{array}{l}\text { Amino Acid } \\
\text { Change }\end{array}$ & Mutation Type \\
\hline \multirow[t]{3}{*}{1} & \multirow[t]{3}{*}{ KS } & \multirow[t]{3}{*}{3} & \multirow[t]{3}{*}{3} & SEMA3E & c. $760 \mathrm{G}>\mathrm{C}$ & p.E254Q & missense \\
\hline & & & & CHD7 & c. $2824 A>G$ & p.T942A & missense \\
\hline & & & & NSMF & c. $188 \mathrm{C}>\mathrm{T}$ & p.P63L & missense \\
\hline \multirow[t]{3}{*}{2} & \multirow[t]{3}{*}{ KS } & \multirow[t]{3}{*}{3} & \multirow[t]{3}{*}{3} & FGFR1 & c.340-344delTTCTC & p.F114fs13 & frameshift \\
\hline & & & & FEZF1 & c. $614 \mathrm{C}>\mathrm{T}$ & p.A205V & missense \\
\hline & & & & FLRT3 & $\mathrm{m} .2556 \mathrm{G}>\mathrm{A}$ & & $\begin{array}{l}\text { noncoding } \\
\text { region }\end{array}$ \\
\hline \multirow[t]{6}{*}{3} & \multirow[t]{6}{*}{$\mathrm{nHH}$} & \multirow[t]{6}{*}{3} & \multirow[t]{6}{*}{4} & PROKR2 & c. $533 \mathrm{G}>\mathrm{C}$ & p.W178S & missense \\
\hline & & & & CHD7 & c. ${ }^{4} 480 \_* 481$ insAGGC & & UTR \\
\hline & & & & CHD7 & c. ${ }^{*} 480 \_* 481$ insCAGTATGCT & & UTR \\
\hline & & & & & CGGGACGCCCTGGCTAAGAA & & \\
\hline & & & & & CATCTACAGCCGCC & & \\
\hline & & & & FGF8 & c. $-72 A>G$ & & UTR \\
\hline \multirow[t]{3}{*}{4} & \multirow[t]{3}{*}{ KS } & \multirow[t]{3}{*}{2} & \multirow[t]{3}{*}{3} & FGFR1 & c. $801 C>G$ & p.Y267Ter & missense \\
\hline & & & & PROKR2 & c. $743 \mathrm{G}>\mathrm{A}$ & p.R248Q & missense \\
\hline & & & & PROKR2 & c. $533 \mathrm{G}>\mathrm{C}$ & p.W178s & missense \\
\hline \multirow[t]{2}{*}{5} & \multirow[t]{2}{*}{ KS } & \multirow[t]{2}{*}{2} & \multirow[t]{2}{*}{2} & FGFR1 & c.1034_c.1035del & p.S345Cfs54* & frameshift \\
\hline & & & & ANOS1 & c. $907 \mathrm{G}>\mathrm{A}$ & p.V303। & missense \\
\hline \multirow[t]{2}{*}{6} & \multirow[t]{2}{*}{ KS } & \multirow[t]{2}{*}{2} & \multirow[t]{2}{*}{2} & FGFR1 & c. $736 \mathrm{C}>\mathrm{T}$ & p.R246W & missense \\
\hline & & & & CHD7 & c. $8250 T>G$ & p.F2750L & missense \\
\hline 7 & KS & 2 & 2 & FGFR1 & c. $1704+1 G>A$ & & splicing site \\
\hline & & & & SPRY4 & $\mathrm{c} .88 \mathrm{C}>\mathrm{T}$ & p.R30W & missense \\
\hline 8 & KS & 2 & 2 & PROKR2 & c. $533 G>C$ & p.W178S & missense \\
\hline & & & & PROK2 & c. $301 \mathrm{C}>\mathrm{T}$ & p.R101W & missense \\
\hline 9 & KS & 2 & 2 & PROKR2 & c. $691 \mathrm{G}>\mathrm{A}$ & p.E231K & missense \\
\hline & & & & IL17RD & c. $192 A>G$ & p.M658V & missense \\
\hline 10 & KS & 2 & 3 & PROKR2 & c. $239 \mathrm{G}>\mathrm{A}$ & p.R80H & missense \\
\hline & & & & PROKR2 & c. $169 \mathrm{G}>\mathrm{T}$ & p.G57C & missense \\
\hline & & & & SEMA3A & c.1453-9delG & & frameshift \\
\hline 11 & KS & 2 & 2 & IL17RD & c. $1319 \mathrm{G}>\mathrm{T}$ & p.G440V & missense \\
\hline & & & & GLI3 & c. $1930 \mathrm{G}>\mathrm{A}$ & p.G644R & missense \\
\hline 12 & KS & 2 & 3 & IL17RD & c. $572 \mathrm{C}>\mathrm{T}$ & p.P191L & missense \\
\hline & & & & ANOS1 & c. $1654 \mathrm{G}>\mathrm{A}$ & p.E552K & missense \\
\hline & & & & ANOS1 & c. $1062+1 \mathrm{G}>\mathrm{A}$ & - & splicing site \\
\hline 13 & KS & 2 & 2 & KISS1R & c. $149 \mathrm{C}>\mathrm{A}$ & p.A50E & missense \\
\hline & & & & CCKBR & c. $1247 \mathrm{G}>\mathrm{A}$ & p.R416H & missense \\
\hline 14 & KS & 2 & 3 & CHD7 & c. $3247 A>G$ & p.T1083A & missense \\
\hline & & & & CHD7 & c. $6379 \mathrm{G}>\mathrm{A}$ & p.A2127T & missense \\
\hline & & & & HS6ST1 & c. $1177 \mathrm{G}>\mathrm{A}$ & p.D393N & missense \\
\hline 15 & KS & 2 & 2 & FGF17 & c. $580 \mathrm{C}>\mathrm{G}$ & p.Q194E & missense \\
\hline & & & & CHD7 & c. $7912 A>G$ & p.I2638V & missense \\
\hline 16 & KS & 2 & 2 & FGFR1 & c. $1439 \mathrm{~T}>\mathrm{G}$ & p.L480X & truncation \\
\hline & & & & SEMA3A & c. $1306 \mathrm{G}>\mathrm{A}$ & p.V436I & missense \\
\hline
\end{tabular}




\begin{tabular}{|c|c|c|c|c|c|c|c|}
\hline \multirow[t]{2}{*}{17} & \multirow[t]{2}{*}{$\mathrm{nHH}$} & \multirow[t]{2}{*}{2} & \multirow[t]{2}{*}{2} & FGFR1 & c. $238 \mathrm{C}>\mathrm{T}$ & p.R80C & missense \\
\hline & & & & sox2 & c. $695 \mathrm{C}>\mathrm{A}$ & p.T232N & missense \\
\hline \multirow[t]{2}{*}{18} & \multirow[t]{2}{*}{$\mathrm{nHH}$} & \multirow[t]{2}{*}{2} & \multirow[t]{2}{*}{2} & FGFR1 & c. $142 \mathrm{G}>\mathrm{A}$ & p.G48S & missense \\
\hline & & & & GLI3 & c. $3286 \mathrm{G}>\mathrm{A}$ & p.V1096M & missense \\
\hline \multirow[t]{2}{*}{19} & \multirow[t]{2}{*}{$\mathrm{nHH}$} & \multirow[t]{2}{*}{2} & \multirow[t]{2}{*}{2} & PROKR2 & c. $308 \mathrm{C}>\mathrm{T}$ & p.A103V & missense \\
\hline & & & & SEMA3E & c. $760 \mathrm{G}>\mathrm{C}$ & p.E254Q & missense \\
\hline \multirow[t]{2}{*}{20} & \multirow[t]{2}{*}{$\mathrm{nHH}$} & \multirow[t]{2}{*}{2} & \multirow[t]{2}{*}{2} & PROKR2 & c. $533 \mathrm{G}>\mathrm{C}$ & p.W178s & missense \\
\hline & & & & CHD7 & c. $6955 \mathrm{C}>\mathrm{T}$ & p.R2319C & missense \\
\hline \multirow[t]{2}{*}{21} & \multirow[t]{2}{*}{$\mathrm{nHH}$} & \multirow[t]{2}{*}{2} & \multirow[t]{2}{*}{2} & sox2 & c. $330 \mathrm{C}>\mathrm{A}$ & p.Y110Ter & missense \\
\hline & & & & SEMA3A & c. $1432 \mathrm{G}>\mathrm{A}$ & p.E478K & missense \\
\hline \multirow[t]{2}{*}{22} & \multirow[t]{2}{*}{$\mathrm{nHH}$} & \multirow[t]{2}{*}{2} & \multirow[t]{2}{*}{2} & sox2 & c. $6955 \mathrm{C}>\mathrm{A}$ & p.T232N & missense \\
\hline & & & & CHD7 & c. $2656 \mathrm{C}>\mathrm{T}$ & p.R886W & missense \\
\hline \multirow[t]{2}{*}{23} & \multirow[t]{2}{*}{$\mathrm{nHH}$} & \multirow[t]{2}{*}{2} & \multirow[t]{2}{*}{2} & HS6ST1 & c. $1177 \mathrm{G}>\mathrm{A}$ & p.D393N & missense \\
\hline & & & & TAC3 & c. $107 \mathrm{G}>\mathrm{A}$ & p.R36H & missense \\
\hline \multirow[t]{2}{*}{24} & \multirow[t]{2}{*}{$\mathrm{nHH}$} & \multirow[t]{2}{*}{2} & \multirow[t]{2}{*}{2} & KISS1R & c. $929 \mathrm{G}>\mathrm{A}$ & p.C310Y & missense \\
\hline & & & & NROB1 & c. $379 \mathrm{G}>\mathrm{A}$ & p.A127T & missense \\
\hline \multirow[t]{3}{*}{25} & \multirow[t]{3}{*}{$\mathrm{nHH}$} & \multirow[t]{3}{*}{2} & 3 & FGFR1 & c. $-55 A>G$ & & $\begin{array}{l}\text { noncoding } \\
\text { region }\end{array}$ \\
\hline & & & & FGFR1 & c. $1825-30 G>A$ & & intron \\
\hline & & & & PROKR2 & c. $533 \mathrm{G}>\mathrm{C}$ & p.W178Se & missense \\
\hline 26 & $\mathrm{nHH}$ & 2 & 2 & WDR11 & c. $386 G>A$ & p.R129H & missense \\
\hline & & & & SEMA3A & c. $2200 C>T$ & p.R734W & missense \\
\hline
\end{tabular}

\section{Figures}


A

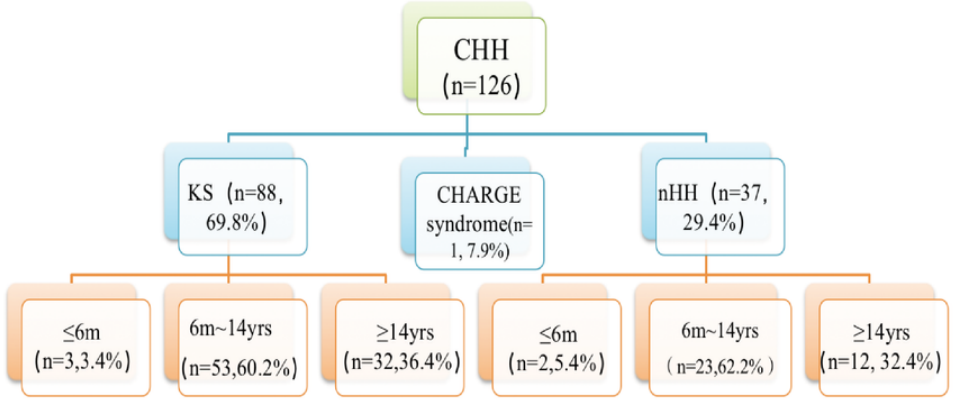

B

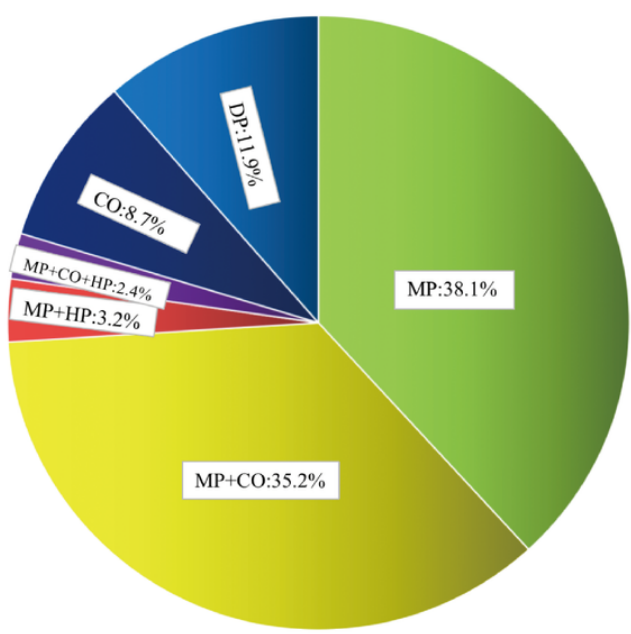

\section{Figure 1}

A: Age distribution of 126 patients with $\mathrm{CHH}$; B: Phenotypic proportion of 126 patients with CHH. MP: micropenis, CO: cryptorchidism; HP: hypospadias; DP: delayed puberty 


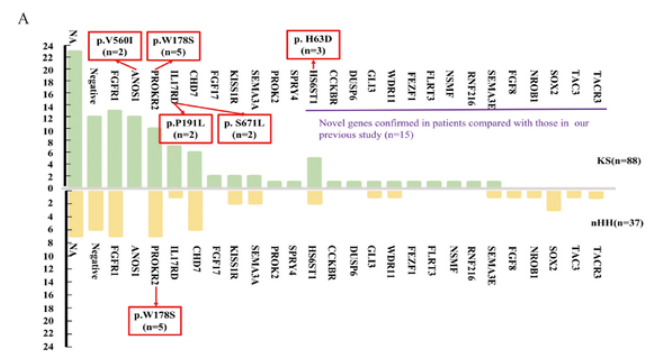

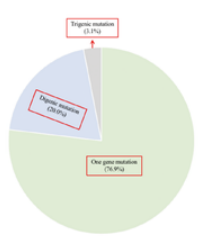
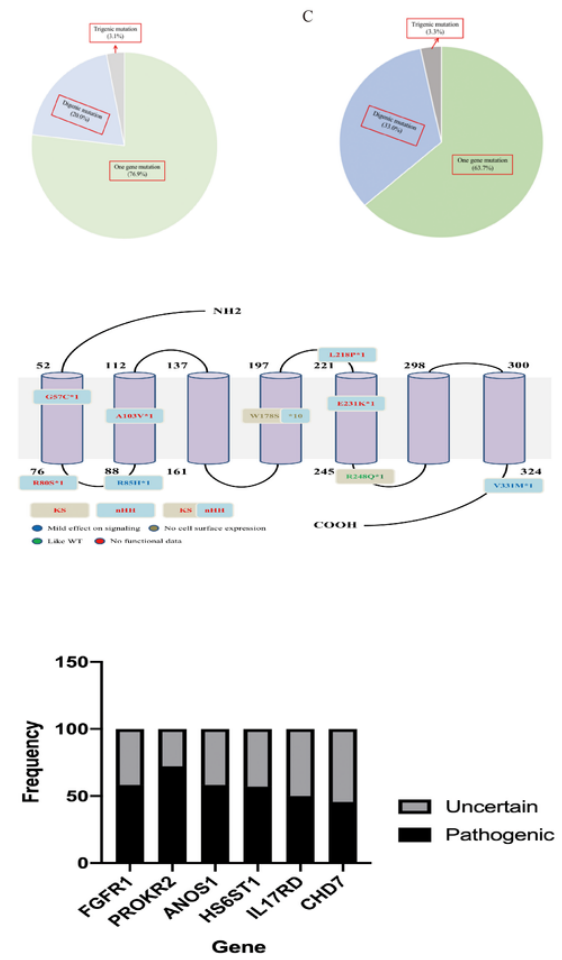

Figure 2

A: The gene distribution of $\mathrm{KS}$ and $\mathrm{nHH}$. As can be seen from the figure, more candidate genes have been confirmed in patients, more than one gene (ANOS1, PROKR2, IL17RD and HS6ST1) have repeated mutation sites. B: The proportion of gene mutations in KS and $\mathrm{nHH}$. Except for single gene mutation, digenic mutation accounted for the majority of oligogenicity. C: The mutation site distribution of PROKR2. PROKR2 was one of the most common genes in CHH patients, and W178S accounted for $58.8 \%$ (10/17), which may could be as the founder mutation of Chinese CHH patients. E: According to the ACMG rule, the pathogenicity proportion of the common gene mutation sites. 


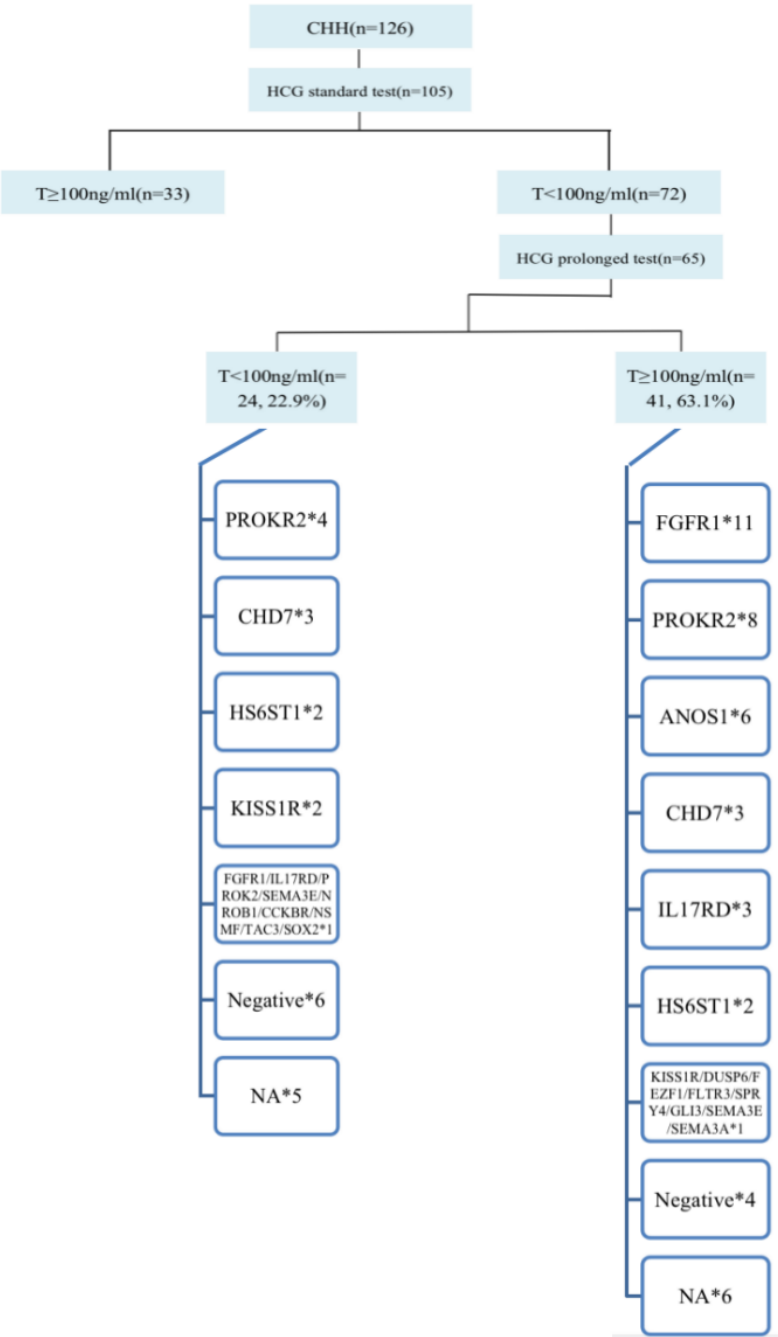

Figure 3

Diagnosis process and gene distribution of dual $\mathrm{CHH}$. 


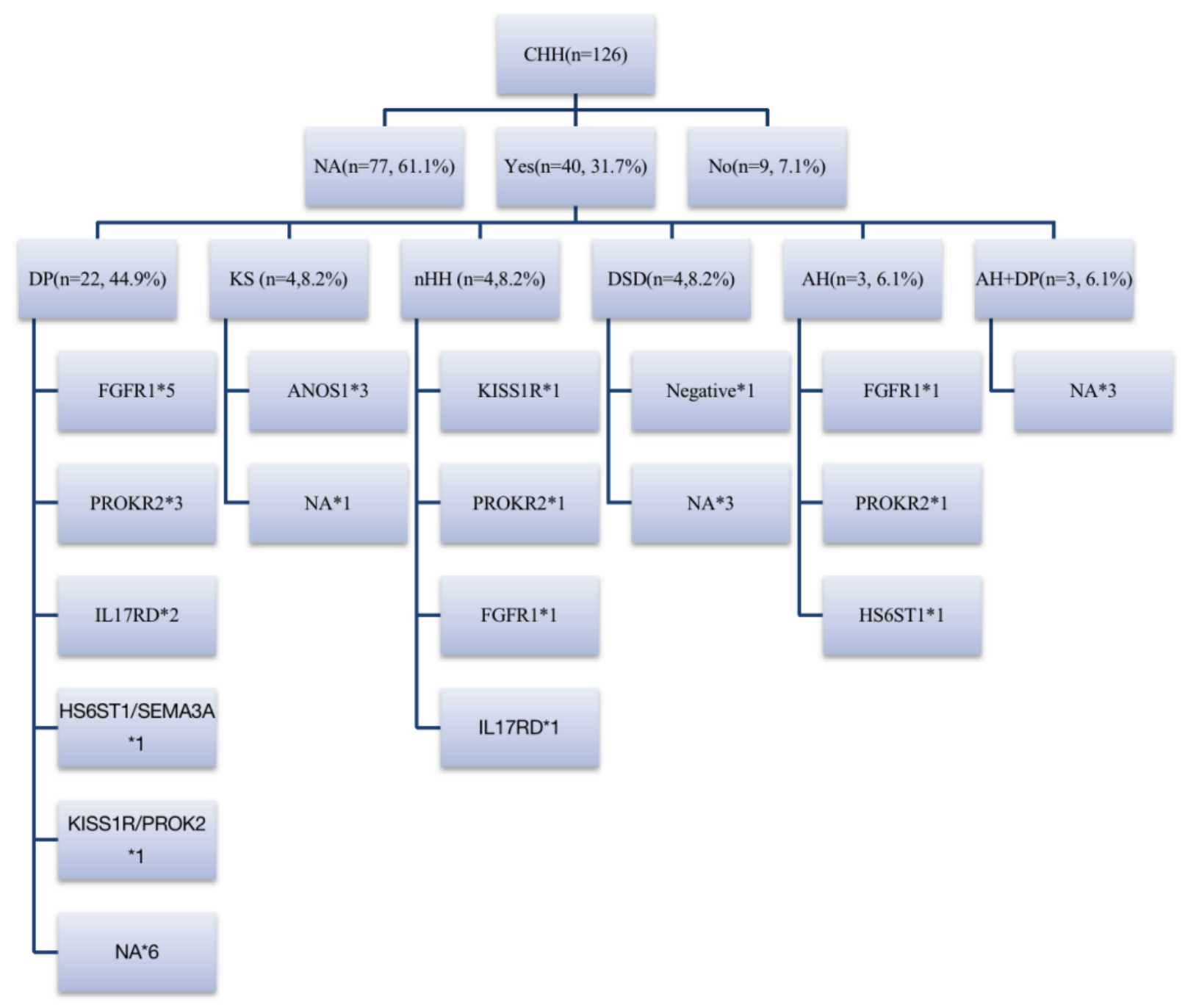

Figure 4

Family history and genes of patients with CHH. DP: delayed puberty, DSD: disorders of sex development, AH: anosmia or hyposmia.

\section{Supplementary Files}

This is a list of supplementary files associated with this preprint. Click to download.

- Supplementarytable1.xlsx 